\title{
GAMBARAN KEPUASAN HIDUP PELAJAR SEKOLAH MENENGAH DI MASA PANDEMI COVID-19
}

\author{
Diana Syamila, Mardy Handika dan Mariana Puspa Sari \\ Universitas Negeri Jakarta, Indonesia \\ Email: dianasyamila@gmail.com,mardyhandika18@gmail.com \\ dan ammahnisa@gmail.com
}

\begin{abstract}
The purpose of this study is to find out the picture of life satisfaction of secondary school students during the Covid-19 pandemic based on the aspects outlined in the research questionnaire. The purpose of this study is to see a picture of student life satisfaction during the covid-19 pandemic. The research method uses descriptive quantitative withdata swearing techniques using Multidimensional Student's Life Satisfaction Scale (MSLSS) with 40 statement items. The number of samples in this study was 125 people with the sample technique used is probability sampling. In the presayarat test analysis using kolmogrov-smirnov and lilliefors using SPSS microsoft for windows versi 25 showed a value of test statistic $0.762>0.05$ and sig. Lilliefors $0.606>0.05$ is declared normal distributeddata. Based on hasil research obtained the results of sangat tinggi as much as 5\% (6 learners), category tinggi as much as 34\% (42 learners), category cukup as much as 41\% (51 learners), category rendah as much as $13 \%$ (17 learners), and category sangat rendah as much as 7\% (9 learners) on the life satisfactionof adolescent learners in the mas a pandemicCOVID-19. So it can be said that overall students of SMP Muhammadiyah 16 Jakarta, MTs Kafila Jakarta, and SMP Global Islamic School Jakarta; havea goodlife satisfaction,this indicates that in the covid-19 pandemic that experienced a change in the situation and limited access in various aspects of life, students are still able to survive and adapt.
\end{abstract}

Keywords: student life satisfaction; secondary school; pandemic covid-19

\begin{abstract}
Abstrak
Tujuan dari penelitian ini adalah untuk mengetahui gambaran kepuasan hidup pelajar sekolah menengah dimasa pandemi Covid-19 berdasarkan aspek-aspek yang telah diuraikan dalam angket penelitian. Metode penelitian menggunakan kuantitatif deskriptif dengan teknik pengumpulan data menggunakan Multidimensional Student's Life Satisfaction Scale (MSLSS) dengan 40 butir pernyataan. Jumlah sampel pada penelitian ini adalah 125 orang dengan teknik sampel yang digunakan adalah probability sampling. Pada uji prasayarat analisis menggunakan kolmogrov-smirnov dan lilliefors dengan menggunakan SPSS microsoft for windows versi 25 menunjukkan nilai test statistic 0,762 >0,05 dan sig. Lilliefors 0,606 > 0,05 dinyatakan data berdistribusi normal. Berdasarkan hasil penelitian diperoleh hasil sangat tinggi sebanyak 5\% (6 peserta didik), kategori tinggi sebanyak 34\% (42 peserta didik), kategori cukup sebanyak 41\% (51 peserta didik), kategori rendah sebanyak 13\% (17 peserta didik), dan kategori sangat
\end{abstract}


rendah sebanyak 7\% (9 peserta didik) pada kepuasan hidup peserta didik usia remaja di masa pandemi COVID-19. Sehingga dapat dikatakan bahwa secara keseluruhan peserta didik SMP Muhammadiyah 16 Jakarta, MTs Kafila Jakarta, dan SMP Global Islamic School Jakarta; memiliki kepuasan hidup yang cukup, ini menandakan bahwa di masa pandemi COVID-19 yang mengalami perubahan situasi serta keterbatasan akses dalam berbagai aspek kehidupan, peserta didik masih mampu bertahan dan beradaptasi.

Kata kunci : kepuasan hidup pelajar; sekolah menengah; pandemi covid-19

Coresponden Author

Email: dianasyamila@gmail.com Artikel dengan akses terbuka dibawah lisensi

\section{Pendahuluan}

Tantangan baru di masa pandemi COVID-19 yang dihadapi tenaga pendidik di sektor pendidikan adalah adanya transformasi proses pembelajaran dari tatap muka menjadi tatap layar (daring). Pembelajaran daring diberlakukan sebagai upaya efektif untuk mengatur proses pembelajaran agar materi tetap tersampaikan dan kegiatan belajar tetap terlaksana sebagaimana mestinya. Upaya tersebut guna mengatur jarak fisik dan sosial untuk menghambat penyebaran COVID-19. Kebijakan baru tentu menimbulkan dampak baru yang beragam, mulai dari kesiapan sekolah, guru, anak-anak maupun orang tua. Teknologi saat ini memiliki peran penting dalam pembelajaran, karena potensi guru bisa diperkuat dengan hadirnya teknologi tersebut (Kemendikbud, 2020).

Keharusan belajar secara daring membuat sekolah melakukan berbagai upaya untuk memenuhi kebutuhan belajar para peserta didik di tengah tuntutan kurikulum yang ada. Proses pembelajaran daring yang merupakan upaya untuk mengurangi penyebaran Virus Corona sehingga mesti dilakukan secara jarak jauh, memerlukan fasilitas yang memadai guna menunjang proses pembelajaran (Sadikin \& Hamidah, 2020). Fasilitas yang memadai akan memberikan kepuasan kepada pelajar secara tidak langsung guna menunjang peningkatan dan keberhasilan akademiknya. Peralatan dan perlengkapan yang tersedia mempunyai pengaruh besar terhadap program belajarmengajar, sebab dengan keterlengkapan teknologi tersebut akan mempengaruhi model pembelajaran yang akan membuat mereka nyaman dan bahagia (Sihotang, Nadeak, \& Siregar, 2020).

COVID 19 banyak menghalangi proses pembelajaran dan menambah kompleksita s masalah yang dihadapi para pendidik dan pelajar, baik dalam hal akademik maupun non akademik (Yulianingsih, Suhanadji, Nugroho, \& Mustakim, 2020). Adapun masalah non akademik berupa masalah psikologis yang dihadapi peserta didik sebagai dampak dari proses pembelajaran secara daring yang menjadi kebijakan pemerintah saat ini. Penelitian tentang Pembelajaran Jarak Jauh darurat COVID-19 telah banyak dilaksanakan terutama di Cina, di mana virus COVID-19 berasal (Tlili, Alazet, 
Glenadel, \& Billard, 2016). Namun belum ada penelitian yang spesifik membahas mengenai kepuasan hidup pelajar di masa pandemi Covid khususya di Jakarta. Oleh sebab itu, kepuasan hidup peserta didik menjadi fokus utama penelitian kami dan untuk pengukurannya menggunakan alat ukur MSLSS (mutidimensional student's life satisfaction scale) dalam penelitian ini.

Kepuasan hidup didefinisikan sebagai penilaian individu atas kualitas hidup mereka berdasarkan kriteria pribadi dan terkait dengan perilaku berisiko kesehatan remaja dan aset perkembangan (Cassoni, Marturano, Coimbra, \& Fontaine, 2017). Definisi lain dari kepuasan hidup menurut Campbell dkk adalah evaluasi kesadaran, kognitif dan afektif individu terhadap kualitas hidup (Bradley, Cunningham, \& Gilman, 2014). Kepuasan hidup dinilai bisa mewakili dimensi "kognitif-evaluatif" dari kesejahteraan subjektif (Coudronnière, Bacro, Guimard, \& Muller, 2018) dibantu dengan kemampuan emosional untuk mempertimbangkan dan menimbang beberapa sumber informasi yang berbeda. Ukuran kepuasan hidup berbeda dari ukuran psikopatologi dan dari ukuran kualitas hidup objektif (Padovani et al., 2014). Kepuasan hidup pelajar terkait dengan kesehatan remaja dan asset perkembangannya (Valois et al., 2019).

Oleh sebab itu, para ahli merancang alat ukur yang berbeda untuk mengukur kepuasan hidup dewasa dan anak-anak. MSLSS dikembangkan dengan tujuan memberikan ukuran kepuasan hidup anak-anak dan remaja dari usia 8-18 ((Huebner, Zullig, \& Saha, 2012). Gilman, dkk menyatakan bahwa MSLSS bisa dipahami sebagai konstruksi ekologis yang terdiri dari multi-tingkat kontekstual (Veronese \& Pepe, 2018). Pada peneltian sebelumnya, kepuasan hidup anak dan remaja dianggap sebagai kunci dari kesehatan mental meski mereka hidup di masa peperangan (Veronese dkk, 2017). Ada lima komponen yang digambarkan dalam MSLSS, yaitu: sekolah (McPartland \& Epstein, 1977), keluarga (Henry, Blazich, \& Hinesley, 1992), teman sebaya (Asher, Hymel, \& Renshaw, 1984), diri sendiri (Asher et al., 1984) dan lingkungan sekitar (Homel \& Burns, 1989).

Institusi pendidikan, salah satunya sekolah adalah aspek yang terkait dengan kepuasan hidup pelajar (Lodi, Boerchi, Magnano, \& Patrizi, 2019). (Peterson, 2006) berpendapat bahwa sekolah adalah institusi yang ideal untuk mendorong perkembangan akademik, karakter dan kesejahteraan pelajar (Kern, Waters, Adler, \& White, 2015). Dengan segala tantangan yang di hadapi, tujuan penelitian kami adalah mendapatkan gambaran secara lebih jelas terkait kepuasan hidup para pelajar sekolah menengah di masa pandemi. Manfaat dari penelitian ini ada dua, yaitu: menunjukkan seberapa besar komponen sekolah membawa dampak kepuasan dalam hidup para pelajar di masa pandemi Covid-19 dan memberi gambaran seberapa besar faktor-faktor selain sekolah mempengaruhi kepuasan hidup pelajar di masa pandemi seperti sekarang ini.

\section{Metode Penelitian}

Penelitian ini menggunakan metode deskriptif dengan pendekatan kuantitatif. (Syofyan Siregar: 15, 2015) Penelitian deskriptif adalah penelitian yang dilakukan 
untuk mengetahui nilai variabel mandiri, baik satu variabel atau lebih (Independent) tanpa membuat perbandingan atau penghubungan dengan dengan variabel lain. Sampel pada penelitian ini berjumlah 125 responden yang merupakan sekumpulan peserta didik dari tiga sekolah swasta di Jakarta, yaitu SMP Muhammadiyah 16 Jakarta, MTs Kafila Jakarta, dan SMP Global Islamic School Jakarta yang berusia 12-15 tahun. Teknik pengambilan sampel pada penelitian ini adalah probability sampling. Teknik ini dipilih karena besar populasi sudah diketahui secara pasti dan seluruh populasi memiliki kesempatan yang sama untuk menjadi sampel (Riduan, 2015).

Pengambilan data menggunakan kuesioner yang disebarkan secara online. Kuesioner menggunakan instrumen MSLSS (multidimensional student's life satisfaction scale) yang telah diadaptasi ke dalam bahasa Indonesia. Proses analisis data menggunakan software SPSS for windows versi 25. Penelitian ini bertujuan untuk melihat bagaimana kepuasan hidup peserta didik selama masa pandemi COVID-19. berdasarkan fakta yang diperoleh. Hasilnya bisa menjadi rekomendasi bagi Guru Bimbingan Konseling dalam pemberian layanan di sekolah masing-masing.

\section{Hasil dan Pembahasan}

Pada tahap pelaksanaan, Instrumen yang dipilih diterjemahkan terlebih dahulu ke dalam Bahasa Indonesia atau forward translation (Sri Rahayu dan Hsing-Mei Chen, 2020). Instrumen Multidimensional Student's Life Satisfaction Scale diterjemahkan ke dalam bahasa Indonesia oleh Siti Nurul Hidayah, M. Pd. Berikutnya, instrumen MSLSS diterjemahkan kembali dari Bahasa Indonesia ke Bahasa Inggris atau backward translation (Rahayu \& Chen, 2020). Penerjemahan kedua dilakukan oleh Ilham Riani, S. Pd. Kedua penerjemah adalah guru yang berlatar belakang pendidikan Bahasa Inggris di institusi pendidikan formal. Forward dan backward translation dilakukan untuk mengetahui konsistensi bahasa yang digunakan dalam instrumen.

Dua orang ahli juga dihadirkan untuk mendukung penggunaan alat tes ini. Satu orang ahli berasal dari S2 BK, bernama Nunung Widyaningsih, M. Pd. Satu orang lagi berasal dari Pendidikan Bahasa Inggris, yaitu Dede Nur Hidayat, M. Pd. Setelah melalui proses penerjemahan, instrumen melalui review dari dua orang ahli lalu diujikan kepada peserta didik maka dilakukan Uji kelayakan isntrumen yang dikenal dengan uji validitas dan reliabilitas. (Siregar, 2015) berpendapat bahwa validitas atau kesahihan menunjukkan sejauh mana suatu alat ukur mampu mengukur apa yang ingin diukur ( $a$ valid measure if it succesfully measure the phenomenon). Mengacu kepada defenisi tersebut uji validitas sangat penting untuk menunjukkan kelayakan atau keasbsahan suatu alat ukur. Sementara Pada uji reliabilitas mengacu kepada keterpercayaan atau konsistensi hasil ukur, yang mengandung makna seberapa tinggi kecermatan pengukuran (Azwar, 2012).

Proses analisis data dilakukan dengan menggunakan SPSS versi 25 untuk mengetahui validitas dan reliabilitas data. Uji validitas instrumen memiliki tujuan untuk mengkonfirmasi apakah instrumen yang digunakan layak digunakan atau tidak. Uji validitas instrumen dilakukan dengan menggunakan product moment. 
Hasil uji validitas data dengan 40 item penyataan menujukkan bahwa instrument valid dan reliabel dengan menggunakan cronbach's alpha. Kemudian, pada uji normalitas data, ditemukan data berdistribusi normal. Dengan sudah mendapatkan validitas dan reliabilitas instrumen, dilakukan penelitian dengan menyebarkan instrumen secara online kepada 125 responden berusia remaja.

Menurut (Sukardi, 2019), instrumen penelitian dikategorikan memiliki nilai reliabilitas yang tinggi apabila hasil uji coba memiliki alpha > 0.6. Perhitungan reliabilitas dilakukan dengan menggunakan SPSS seperti tabel di bawah ini,

Tabel 1

Realibility Statistics

\begin{tabular}{cc}
\hline Cronbach's Alpha & N of Items \\
\hline 747 & 40 \\
\hline
\end{tabular}

Berdasarkan tabel diatas, didapatkan reliabilitas instrumen dengan nilai 0,747. Angka tersebut menunjukan lebih besar dari nilai minimal alpha cronbach yaitu 0,6. Kesimpulannya instrumen yang digunakan pada penelitian ini terkategorikan reliabel dan layak digunakan sebagai alat ukur.

Tabel 2

One-Sample Kolmogorov-Smirnov Test

\begin{tabular}{lll}
\hline $\mathrm{N}$ & & 125 \\
\cline { 2 - 3 } Normal Parameters & Mean & 182,0720 \\
\cline { 2 - 3 } & Std. Deviaton & 22,08750 \\
\cline { 2 - 3 } & Absolute & .068 \\
\cline { 2 - 3 } & Positive & .044 \\
\cline { 2 - 3 } & Negative & -.068 \\
\hline Test Statistic & .762 \\
\hline Asymp. Sig. (2-tailed) & .606 \\
\hline a.Test distribution is Normal. & \\
b. Calculated from data. & \\
c.Lilliefors Significance Correction. &
\end{tabular}

Uji normalitas kolmogrov-smirnov dan lilliefors dengan menggunakan SPSS microsoft for windows versi 25 menunjukkan nilai test statistic 0,762>0,05 dan sig. lilliefors 0,606 > 0,05. Hasil tersebut menggambarkan bahwa data yang diperoleh berdistribusi normal. Selanjutnya data melalui tahap kategorisasi untuk melakukan analisis. Instrumen yang diadaptasi tidak menjelaskan kategorisasi, sehingga dalam penelitian ini menggunakan lima tingkatan menurut (Wayan, N., 1989), yaitu: Sangat Tinggi, Tinggi, Cukup, Rendah, dan Sangat Rendah. 
Tabel 3

Pedoman Kategori Menurut (Wayan, N., 1989)

\begin{tabular}{ccc}
\hline Kategori & Jumlah & Persentase \\
\hline Sangat Tinggi & 6 & $5 \%$ \\
\hline Tinggi & 42 & $34 \%$ \\
\hline Cukup & 51 & $41 \%$ \\
\hline Rendah & 17 & $13 \%$ \\
\hline Sangat Rendah & 9 & $7 \%$ \\
\hline Total & 125 & $100 \%$ \\
\hline
\end{tabular}

Hasil perhitungan data didapatkan melalui hasil dari penjumlahan skor setiap item, kemudian dihitung rata-ratanya serta dapat dipersentasekan untuk melihat kategorisasi datanya sebagai gambaran kepuasan hidup pelajar di tiga sekolah yang kami teliti selama masa pandemi COVID-19.

Tabel 4

Persentase Life Satisfaction Peserta Didik SMP Swasta Jakarta

\begin{tabular}{cc}
\hline Nilai Akhir (\%) & Kategori Konversi \\
\hline $90 \%-100 \%$ & Sangat Tinggi \\
\hline $80-89 \%$ & Tinggi \\
\hline $70-79 \%$ & Cukup \\
\hline $60-69 \%$ & Rendah \\
\hline$<60 \%$ & Sangat Rendah
\end{tabular}

Tabel 5

Diagram Life Satisfaction

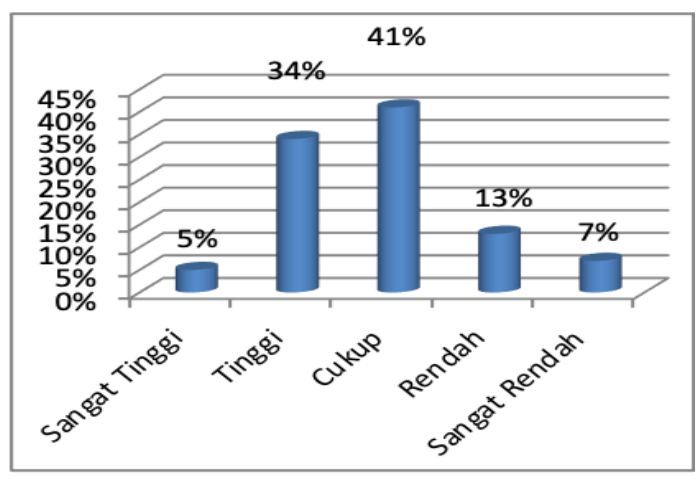

Berdasarkan pengolahan data penelitian dengan jumlah sampel 125 peserta didik tiga SMP Swasta di Jakarta, diperoleh hasil tingkat kepuasan hidup pelajar dalam kategori Sangat Tinggi sebanyak 5\% (6 peserta didik), kategori Tinggi sebanyak 34\% (42 peserta didik), kategori Cukup sebanyak 41\% (51 peserta didik), kategori Rendah sebanyak 13\% (17 peserta didik), dan kategori Sangat Rendah sebanyak 7\% (9 peserta didik) pada kepuasan hidup pelajar usia remaja di masa pandemi COVID-19. 
Persentase terbesar yang digambarkan melalui penelitian tentang kepuasan hidup pelajar saat ini adalah pada kategori Cukup. Penilaian kepuasan hidup dikaitkan dengan kebahagiaan(Pavot \& Diener, 2008); (Emmons, 2003).

Ketika merujuk pada teori tersebut, di masa pandemi ini, kepuasan hidup peserta didik berada di level Cukup Puas. (Schimmack, Oishi, \& Diener, 2002) meneliti kepuasan individu yang berulang dari waktu ke waktu karena bergantung pada jenis informasi yang sama. Penelitian itu juga menemukan fakta bahwa ketika sumber informasi yang digunakan dalam perumusan kepuasan hidup berubah, tingkat kepuasan hidup yang dilaporkan juga berubah.

Berdasarkan fakta di atas perlu ditelaah lagi, saat pandemi berakhir apakah angka kepuasan hidup peserta didik berada di angka yang berbeda. Perbedaan tersebut nantinya bisa berakibat pada naik atau turunnya level kepuasan yang bisa berdampak pada kebahagiaan para pelajar tersebut.

Tabel 6

Persentase Dimensi MSLSS

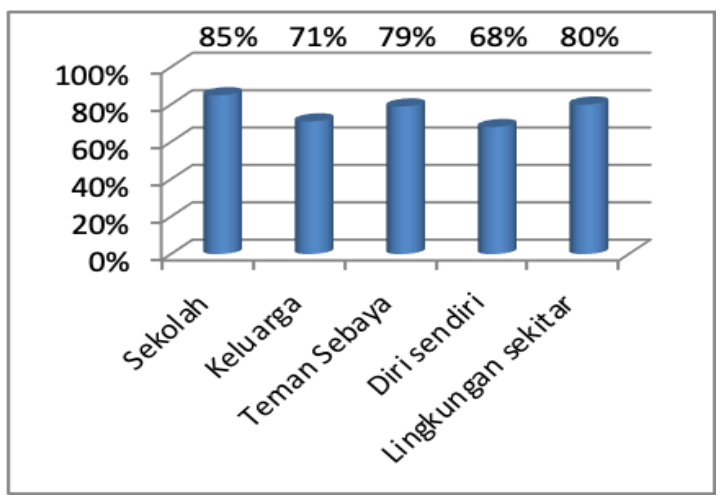

Merujuk pada tabel kategori menurut (Wayan, N., 1989) serta diagram persentase dimensi instrumen life satisfaction tersebut, dapat terlihat bahwa pada dimensi Keluarga diperoleh hasil $71 \%$ yang berarti berada pada kategori Cukup, dimensi Teman Sebaya sebanyak $79 \%$ yang berarti Cukup, dimensi Sekolah sebanyak $85 \%$ yang berarti Tinggi, dimensi Lingkungan Sekitar sebanyak $80 \%$ yang berarti Tinggi, dan dimensi Diri Sendiri sebanyak $68 \%$ yang berarti Rendah.

Ditinjau dari teori Kepuasan hidup pelajar (Huebner \& Gilman, 2002) yang terdiri dari lima aspek. Sekolah dan lingkungan sekitar memberikan persentasi terbesar dalam kepuasan mereka. Disusul oleh teman sebaya dan keluarga yang menempati level cukup bagi kepuasan hidup pelajar. Level terendah yang bersumbangsih pada kepuasan hidup mereka adalah diri sendiri.

\section{Kesimpulan}

Hasil penelitian yang dilakukan menunjukkan bahwa kepuasan hidup peserta didik di SMP Muhammadiyah 16 Jakarta, MTs Kafila Jakarta, dan SMP Global Islamic School Jakarta; memperoleh hasil Sangat Tinggi sebanyak 5\% (6 orang), kategori Tinggi sebanyak 34\% (42 orang), kategori Cukup sebanyak 41\% (51 orang), kategori 
Rendah sebanyak 13\% (17 orang), dan kategori Sangat Rendah sebanyak 7\% (9 orang) pada kepuasan hidup peserta didik usia remaja di masa pandemi COVID-19.

Dapat disimpulkan bahwa secara keseluruhan pelajar SMP Muhammadiyah 16 Jakarta, MTs Kafila Jakarta, dan SMP Global Islamic School Jakarta; memiliki kepuasan hidup yang Cukup, ini menandakan bahwa di masa pandemi COVID-19 yang mengalami perubahan situasi serta keterbatasan akses dalam berbagai aspek kehidupan, peserta didik masih mampu bertahan dan beradaptasi.

Hal lain yang didapatkan dari penelitian ini adalah keluarga bukanlah faktor pertama yang mempengaruhi kepuasan hidup pelajar. Selain itu, diri sendiri menjadi faktor terendah yang berkontribusi dalam kepuasan hidup para pelajar sekolah menengah di Jakarta.

Perlu telaah lebih jauh untuk dua temuan terakhir. Kepuasan hidup pelajar pasca pandemi juga bisa direkomendasikan untuk penelitian lanjutan. Sebagai pembanding yang signifikan antara saat pandemi dan setelah pandemi berakhir. 


\section{BIBLIOGRAFI}

Asher, Steven R., Hymel, Shelley, \& Renshaw, Peter D. (1984). Loneliness in children. Child Development, 1456-1464.

Azwar, Saifuddin. (2012). Penyusunan skala psikologi edisi II. Yogyakarta: Pustaka Pelajar.

Bradley, Kelly D., Cunningham, Jessica D., \& Gilman, Richard. (2014). Measuring adolescent life satisfaction: A psychometric investigation of the Multidimensional Students' Life Satisfaction Scale (MSLSS). Journal of Happiness Studies, 15(6), 1333-1345.

Cassoni, Cynthia, Marturano, Edna Maria, Coimbra, Susana, \& Fontaine, Anne Marie. (2017). A validation study of the Multidimensional Life Satisfaction Scale for Children. Psicologia: Reflexão e Crítica, 30.

Coudronnière, Charlotte, Bacro, Fabien, Guimard, Philippe, \& Muller, Jean Baptiste. (2018). Validation of a French adaptation of the Multidimensional Student's Life Satisfaction Scale in its abbreviated form, for 5-to 11-year-old children with and without intellectual disability. Journal of Intellectual \& Developmental Disability, 43(4), 407-420.

Emmons, Robert A. (2003). Personal goals, life meaning, and virtue: wellsprings of a positive life.

Forzano, Gravetter. (2009). Branch point and donor splice-site COL7A1 mutations in mild recessive dystrophic epidermolysis bullosa. British Journal of Dermatology, 161(2), 464-467.

Henry, Paul H., Blazich, Frank A., \& Hinesley, L. Eric. (1992). Nitrogen nutrition of containerized eastern redcedar. II. Influence of stock plant fertility on adventitious rooting of stem cuttings. Journal of the American Society for Horticultural Science, 117(4), 568-570.

Homel, Ross, \& Burns, Ailsa. (1989). Environmental quality and the well-being of children. Social Indicators Research, 21(2), 133-158.

Huebner, E. Scott, \& Gilman, Rich. (2002). An introduction to the multidimensional students' life satisfaction scale. Social Indicators Research, 60(1), 115-122.

Huebner, E. Scott, Zullig, Keith J., \& Saha, Runa. (2012). Factor structure and reliability of an abbreviated version of the Multidimensional Students' Life Satisfaction Scale. Child Indicators Research, 5(4), 651-657.

Kemendikbud, Simkeu. (2020). UU No. 20 Tahun 2003 Tentang Sistem Pendidikan Nasional. Diakses. 
Kern, Margaret L., Waters, Lea E., Adler, Alejandro, \& White, Mathew A. (2015). A multidimensional approach to measuring well-being in students: Application of the PERMA framework. The Journal of Positive Psychology, 10(3), 262-271.

Lodi, Ernesto, Boerchi, Diego, Magnano, Paola, \& Patrizi, Patrizia. (2019). HighSchool Satisfaction Scale (H-Sat Scale): Evaluation of Contextual Satisfaction in Relation to High-School Students' Life Satisfaction. Behavioral Sciences, 9(12), 125.

McPartland, James M., \& Epstein, Joyce L. (1977). Open schools and achievement: Extended tests of a finding of no relationship. Sociology of Education, 133-144.

Padovani, Ricardo da Costa, Neufeld, Carmem Beatriz, Maltoni, Juliana, Barbosa, Leopoldo Nelson Fernandes, Souza, Wanderson Fernandes de, Cavalcanti, Helton Alexsandro Firmino, \& Lameu, Joelma do Nascimento. (2014). Vulnerabilidade e bem-estar psicológicos do estudante universitário. Revista Brasileira de Terapias Cognitivas, 10(1), 2-10.

Pavot, William, \& Diener, Ed. (2008). The satisfaction with life scale and the emerging construct of life satisfaction. The Journal of Positive Psychology, 3(2), 137-152.

Peterson, Christopher. (2006). A primer in positive psychology. Oxford university press. Rahayu, Sri, \& Chen, Hsing Mei. (2020). Penerjemahan Dan Validasi Kuesioner "Educational Needs Of Caregivers Instrument" Ke Dalam Bahasa Indonesia Pada Caregivers Pasien Gagal Jantung. Jurnal Kesehatan, 13(1), 35-45.

Sadikin, Ali, \& Hamidah, Afreni. (2020). Pembelajaran Daring di Tengah Wabah Covid-19:(Online Learning in the Middle of the Covid-19 Pandemic). Biodik, 6(2), 214-224.

Schimmack, Ulrich, Oishi, Shigehiro, \& Diener, Ed. (2002). Cultural influences on the relation between pleasant emotions and unpleasant emotions: Asian dialectic philosophies or individualism-collectivism? Cognition \& Emotion, 16(6), 705-719.

Sihotang, Hotmaulina, Nadeak, Bernadetha, \& Siregar, Rospita. (2020). Penerapan Belajar Mandiri dengan Strategi Efektif pada Masa Pandemi Covid-19 Bagi Remaja HKBP Duren Jaya Bekasi. JURNAL ComunitÃ Servizio: Jurnal Terkait Kegiatan Pengabdian Kepada Masyarakat, Terkhusus Bidang Teknologi, Kewirausahaan Dan Sosial Kemasyarakatan, 2(2), 393-405.

Siregar, Syofian. (2015). Statistik Parametrik untuk Penelitian Kuantitatif di Lengkapi dengan Perbandingan Perhitungan Menual \& SPSS Versi 17. Cet. II.

Sugiyono, M. P. P., \& Kuantitatif, P. (2009). Kualitatif, dan R\&D, Bandung: Alfabeta. Cet. VII.

Sukardi. (2019). Metode Penelitian Pendidikan Kompetensi dan Praktiknya. Jakarta: Bumi Aksara. 
Tlili, Anis, Alazet, Sébastien, Glenadel, Quentin, \& Billard, Thierry. (2016). Copper-Catalyzed Perfluoroalkylthiolation of Alkynes with Perfluoroalkanesulfenamides. Chemistry-A European Journal, 22(29), 1023010234.

Valois, Robert F., Zullig, Keith J., Brown, Larry K., Carey, Michael P., Vanable, Peter A., Romer, Daniel, \& DiClemente, Ralph J. (2019). Is the Brief Multidimensional Student's Life Satisfaction Scale Valid and Reliable for African American Adolescents? American Journal of Health Education, 50(6), 344-355.

Veronese, Guido, \& Pepe, Alessandro. (2018). Cross-cultural adaptation, psychometric proprieties and factor structure of the Multidimensional Student Life Satisfaction Scale (MSLSS): A study with Palestinian children living in refugee camps. Current Psychology, 1-10.

Wayan, N., \&. Sumartana. (1989). Evaluasi Pendidikan.

Yulianingsih, Wiwin, Suhanadji, Suhanadji, Nugroho, Rivo, \& Mustakim, Mustakim. (2020). Keterlibatan Orangtua dalam Pendampingan Belajar Anak selama Masa Pandemi Covid-19. Jurnal Obsesi: Jurnal Pendidikan Anak Usia Dini, 5(2), 11381150 . 